\title{
ANTI-INFLAMMATORY ACTIVITY OF TINOCRISPOSIDE BY INHIBITING NITRIC OXIDE PRODUCTION IN LIPOPOLYSACCHARIDES-STIMULATED RAW 264.7 CELLS
}

\author{
ADEK ZAMRUD ADNAN ${ }^{1}$, MUHAMMAD TAHER ${ }^{2}$, TIKA AFRIANI ${ }^{3}$, ANNISA FAUZANA ${ }^{1}$, DEWI IMELDA ROESMA ${ }^{4}$, \\ ANDANI EKA PUTRA ${ }^{5}$ \\ ${ }^{1}$ Department of Pharmaceutical Chemistry, Faculty of Pharmacy, Andalas University, Padang, Indonesia. ${ }^{2}$ Department of Pharmaceutical \\ Technology, Faculty of Pharmacy, International Islamic University Malaysia, 25200 Kuantan, Malaysia. ${ }^{3}$ Department of Pharmacy, \\ Mohammad Natsir University, Bukittinggi 26136, Indonesia. ${ }^{4}$ Department of Biology, Andalas University, Indonesia. ${ }^{5}$ Department of \\ Microbiology, Medicinal Faculty, Andalas, University, Indonesia. Email: adekzamrudadnan@phar.unand.ac.id
}

Received: 20 November 2017, Revised and Accepted: 27 December 2017

Objective: The aim of this study was to investigate in vitro anti-inflammatory activity of tinocrisposide using lipopolysaccharides (LPS)-stimulated RAW 264.7 macrophage cells. Tinocrisposide is a furano diterpene glycoside that was isolated in our previous study from Tinospora crispa.

Methods: Anti-inflammatory effect was quantified spectrometrically using Griess method by measuring nitric oxide (NO) production after the addition of Griess reagent.

Results: The sample concentrations of 1, 5, 25, 50, and $100 \mu \mathrm{M}$ and $100 \mu \mathrm{M}$ of dexamethasone (positive control) have been tested against the LPSstimulated RAW 264.7 cells, and the results showed NO level production of 39.23, 34.00, 28.9, 20.25, 16.3, and $13.68 \mu \mathrm{M}$, respectively, and the inhibition level of $22.67,33.00,43.03,60.10,68.00$, and $73 \%$, respectively.

Conclusions: From the study, it could be concluded that tinocrisposide was able to inhibit the formation of NO in the LPS-stimulated RAW 264.7 cells in concentration activity-dependent manner, with half-maximal inhibition concentration $46.92 \mu \mathrm{M}$. It can be developed as anti-inflammatory candidate drug because NO is a reactive nitrogen species which is produced by NO synthase. The production of NO has been established as a mediator in inflammatory diseases.

Keywords: Anti-inflammatory activity, Griess method, Tinocrisposide, Tinospora crispa.

(c) 2018 The Authors. Published by Innovare Academic Sciences Pvt Ltd. This is an open access article under the CC BY license (http://creativecommons. org/licenses/by/4. 0/) DOI: http://dx.doi.org/10.22159/ajpcr.2018.v11i4.23739

\section{INTRODUCTION}

Tinospora crispa is a climber plant widely distributed from the Southwestern part of China to Southeast Asia including Indonesia, Malaysia, Vietnam, Thailand, and India. This bitter tasted plant locally known as brotowali $[1,2]$. It has been used as traditional medicine in Indonesia, Malaysia, and Thailand to treat fever, diabetes, cholera, rheumatism, reducing thirst, hypertension, increasing appetite, and protection from mosquito bites. The crushed leaves are applied on wounds and made into a poultice for itch [1,3]. It was reported that the aqueous extract of T. crispa has been showed anti-inflammatory activity using the carrageenan-induced paw edema test [4] and also reported to suppress the synthesis and release of nitric oxide (NO) in lipopolysaccharides (LPS)-stimulated murine macrophages [5]. The methanolic and aqueous extract of T. crispa displayed a dosedependent cytotoxic effect on MCF-7, HeLa, and Caov-3 cell lines with an half-maximal inhibition concentration $\left(\mathrm{IC}_{50}\right)$ value of $33.8,165$, and $100 \mu \mathrm{g} / \mathrm{ml}$, respectively $[6,7]$.

From methanol extract of dried pulvered T. crispa stems, we have isolated tinocrisposide $\left(\mathrm{C}_{27} \mathrm{H}_{36} \mathrm{O}_{11}\right)$, a furano diterpene glycoside with very bitter taste. This work has been reported in Arch Pharm [8]. An antiinflammatory effect of tinocrisposide has been investigated in vivo in our previous study and reported in $43^{\text {rd }}$ GA-Congress in Halle, Germany [9].

Inflammation is a physiological response of a body to infection or tissue injury [10] which can be caused by different stimuli such as bacterial infection, physical and chemical factors, immunological reactions, and tissue damage $[11,12]$. Inflammations may be acute or chronic. Acute inflammation is believed to be a defensive mechanism to aid in the killing of bacteria, virus, and/or parasites, eliminate irritants, and maintain normal physiological functions $[13,14]$. The cardinal signs are characterized by redness (rubor), heat (calor), pain (dolor), swelling (tumor), and loss of function [15]. Macrophage plays an important role in the inflammatory response. LPS from the outer membrane of Gram-negative bacteria cell walls activates multiple signal pathways in macrophages such as the nuclear factor- $\mathrm{kB}$ pathway that causes inflammation through enhanced cytokine, NO, and prostaglandin production [16-19]. These inflammatory cytokines and mediators play an important role in preventing the spread of infection and also required for repair damaged tissue [20]. However, excessive pro-inflammatory mediators can also promote tissue damage resulting in chronic inflammation [21]. The persistent and prolonged chronic inflammation increases the risk associated with certain generative diseases such as rheumatoid arthritis, atherosclerosis, heart disease, asthma, diabetes, and even cancer [22]. Therefore, finding new anti-inflammatory agents can be a concrete strategy in fighting not only different inflammatory diseases but also cancer.

The anti-inflammatory effect of a new compound or extracts can be conducted by various methods. Uma et al. assessed the in vivo antiinflammatory activity of crude extract of Corbichonia decumbens by carrageenan- and histamine-induced paw edema method [23]. Soundarajan et al. used human keratinocyte cells (HaCaT cells) to identify the inflammatory effect of monocrotophos on cell viability, NO secretion, lactate dehydrogenase release, malondialdehyde release, nuclear changes, reactive oxygen species generation, and cytokine expression [24]. Kusmadi et al. investigated the anti-inflammatory effects of pomegranate peel ethanol extract on mice colon. The study 


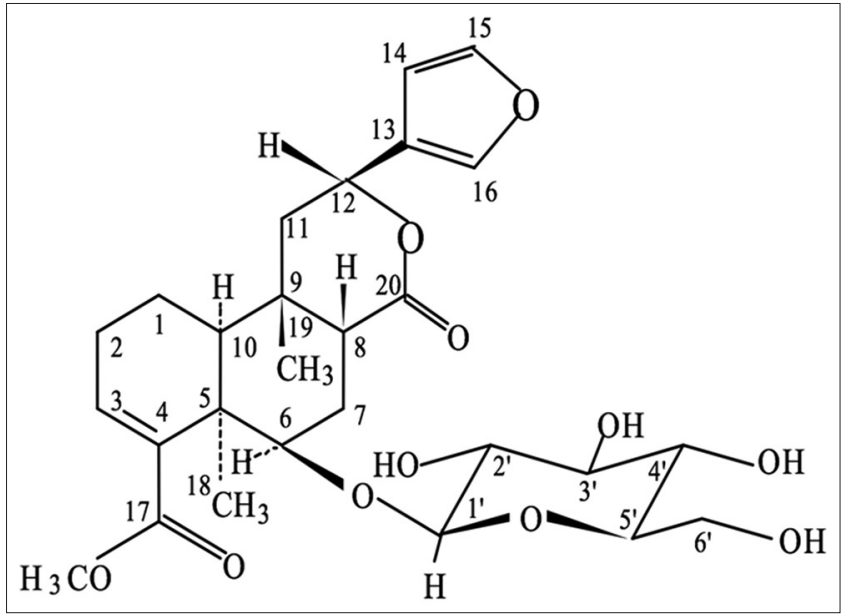

Fig. 1: Chemical structure of tinocrisposide [8]

was done through inflammation pathway and it showed reduction in inflammation score on mice model with chronic inflammation induced by dextran sodium sulfate [25]; meanwhile, Kurian et al. explored an anti-inflammatory property of melanin in vitro in RAW 264.7 cell line using cyclooxygenase, lipoxygenase, myeloperoxidase, and cellular nitrite inhibitory assays [26]. The aim of our study was to investigate in vitro the anti-inflammatory activity of tinocrisposide using the LPSstimulated RAW 264.7 macrophage cells.

\section{METHODS}

\section{Chemicals and reagent}

Dulbecco's modified eagle medium (DMEM), fetal bovine serum (FBS), penicillin-streptomycin (PenStrep), trypsin, and 0.4\% Trypan blue stain were purchased from Gibco (Invitrogen Corporation, USA). Phosphate-buffered saline (PBS) was purchased from Sigma-Aldrich Chemical Co. (St. Louis, USA). 3-(4.5-dimethylthiazol-2-yl)-2.5diphenyltetrazolium bromide (MTT) was purchased from Calbiochem, USA. Dimethylsulfoxide (DMSO) was purchased from Fisher Chemical (Thermo Fisher Scientific, USA). LPS and Griess reagent were purchased from Sigma-Aldrich Chemical Co. (St. Louis, USA). Dichloromethane (DCM), $n$-hexane, acetic acid, ammonia, ethyl acetate, chloroform, and methanol were analytical grade and purchased from Merck, Germany. Silica gel 60 was purchased from Merck Darmstadt, Germany.

\section{Instruments}

Inverted Microscope (TC 5400, Meiji Techno, Japan), Microplate reader (Dynatech MR5000 TECAN, Tecan Group Ltd., Switzerland), Hemocytometer (Hirschmann, EM Techcolor, Germany), Class II biological safety cabinet (Jouan MSC 12, Thermo Fisher Scientific, USA), Light microscope (Motic B2 series, Motic Asia, Hong Kong), Autoclave (HV-85, Hirayama, Japan), $\mathrm{CO}_{2}$ Incubator (NU-5100E, Nuaire, USA), and Centrifuge (Universal 32 R, Hettich Zentrifugen, USA) were used.

\section{Plant materials}

Fresh T. crispa stem samples were collected from Lubuk Minturun, Padang, Indonesia. This plant was identified and authenticated by Dr. Nurainas at the Department of Biology, Faculty of Science, Andalas University. A voucher specimen was deposited in the Herbarium ANDA (No. 178/K-ID/ANDA/V/2015, University of Andalas).

\section{Cell lines}

RAW 264.7 mouse macrophage cells were purchased from American Type Culture Collection (ATCC), Virginia, USA.

\section{Basic procedures in cell culture}

Cells were cultured in complete DMEM medium containing 10\% FBS, $1 \%$ penicillin $(10.000 \mathrm{U} / \mathrm{ml})$, and $1 \%$ streptomycin $(10.000 \mu \mathrm{g} / \mathrm{ml})$ in $37^{\circ} \mathrm{C}$ incubator with $5 \%$ of $\mathrm{CO}_{2}$ atmosphere.

\section{Experimental procedures \\ Extraction and isolation}

The dried and powdered stem ( $3.2 \mathrm{~kg}$ ) of T. crispa was extracted using $\mathrm{n}$-hexane and methanol, successively through maceration process for 3 times for 3 days each at room temperature. The crude methanol extracts $(273 \mathrm{~g})$ were dissolved in acetic acid 5\% for overnight, decanted, and then partitioned, sequentially, with n-hexane and DCM. Each fraction was dried to yield n-hexane and DCM fractions. The water fraction was basified with ammonia until $\mathrm{pH} 9$ and then partitioned with DCM to get DCM base fraction. The neutral $(24.56 \mathrm{~g})$ and base DCM dried fractions (2.64 g) were subjected to column chromatography over silica gel 60 with mobile phase the mixture of DCM and MeOH using step gradient elution system (1-15\% of $\mathrm{MeOH}$ in DCM). The fractions were combined on the basis of thin-layer chromatography (TLC) monitoring. TLC was carried out using Silica gel F254 plate (Merck) as the stationary phase and the mixture of MeOH:DCM (1:9) as the mobile phase. The fractions, which spots have the same $R_{\mathrm{f}}$ values, were combined and further purified by second-column chromatography on silica gel 60 to obtain pure tinocrisposide as white amorphous powder.

\section{Cell viability}

The viability of RAW 264.7 cells was assessed by MTT according to Mosmann method [27]. This experiment was performed to elaborate interval concentration of tinocrisposide that exerts no toxic effect to the cells. RAW 264.7 cells were seeded in 96-well flat bottom tissue culture plate with a density of $2 \times 10^{5} \mathrm{cell} /$ well and grown until confluence at $37^{\circ} \mathrm{C}, 5 \% \mathrm{CO}_{2}$. Supernatants were discarded, and a complete medium contained various concentration of tinocrisposid solutions in DMSO was then added $(3.125-100 \mu \mathrm{g} / \mathrm{ml})$ into each well. The plate was incubated for $24 \mathrm{~h}$ at $37^{\circ} \mathrm{C}, 5 \% \mathrm{CO}_{2}$. Supernatants were discarded, and the cell was then washed 2 times with PBS. $20 \mu \mathrm{l}$ MTT stock solution ( $5 \mathrm{mg} / \mathrm{ml}$ PBS) was added to each well, and the plates were further incubated for $4 \mathrm{~h}$ at $37{ }^{\circ} \mathrm{C}, 5 \% \mathrm{CO}_{2} .100 \mu \mathrm{l}$ of DMSO was added to each well to dissolve the formed water-insoluble purple formazan crystal. After allowing $1 \mathrm{~h}$, the absorbency of each well was measured with a microplate reader (TECAN) at a wavelength of $570 \mathrm{~nm}$.

\section{Solution of sodium nitrite $\left(\mathrm{NaNO}_{2}\right)$ reference}

$6.9 \mathrm{mg}$ of $\mathrm{NaNO}_{2}$ was weighed correctly and transferred into $100 \mathrm{ml}$ volumetric flask, dissolved in $25 \mathrm{~mL}$ of distilled water. The volume was made up with distilled water until $100 \mathrm{ml}$ to get a stock solution of $\mathrm{NaNO}_{2}$ with concentrations of $1000 \mu \mathrm{M}$. A certain volume of stock solution was further diluted with distilled water to get the standard solutions of $\mathrm{NaNO}_{2}$ with concentrations of $100,50,25,12.5,6.25$, and $3.125 \mu \mathrm{M}$, respectively. $25 \mu \mathrm{l}$ of each concentration of standard solutions was mixed with $25 \mu \mathrm{l}$ of Griess reagent $(0.2 \%$ naphthylethylenediamine dihydrochloride and $2 \%$ sulfanilamide in $5 \%$ phosphoric acid), allowed to rest at room temperature for $10 \mathrm{~min}$, and the absorbency of each solution was measured with microplate plate reader at wavelength, $\lambda 560 \mathrm{~nm}$.

\section{NO determination (Griess assay)}

Nitrite accumulation was used as an indicator of NO production in the medium. Released NO (nitrous oxide) to a medium was assayed according to Lee et al. [28] with slight modification. RAW 264.7 cells were plated in 96-well plate with a density of $10^{5}$ cell/well until confluence. Supernatants were discarded and $100 \mu \mathrm{l}$ medium containing various concentrations of tinocrisposide $(1,5,25,50$, and $100 \mu \mathrm{M})$ was added to the cells. The cells were allowed to rest for $1 \mathrm{~h}$ and then incubated with LPS $(1 \mathrm{~g} / \mathrm{ml})$ for $15 \mathrm{~h}$ at $37^{\circ} \mathrm{C}$ in a humidified atmosphere containing $5 \% \mathrm{CO}_{2} 25 \mu \mathrm{L}$ supernatant of each well was transferred into new 96-well plate and was mixed with $25 \mu \mathrm{l}$ Griess reagent $0.2 \%$ naphthylethylenediamine dihydrochloride and $2 \%$ sulfanilamide in $5 \%$ phosphoric acid), allowed to rest at room temperature for $10 \mathrm{~min}$, and then, the absorbency of each solution was measured with microplate plate reader at wavelength of $560 \mathrm{~nm}$. The measured absorbance was calculated using the regression equation of $\mathrm{NaNO}_{2}$ standard solution to get the data of nitrite production concentrations. Inhibition of nitrite production by various concentration of tinocrisposide was then compared to inhibition of dexamethasone, a drug. 
Statistical analysis

All experiments were repeated 3 times $(\mathrm{N}=3)$. The results were represented as mean \pm standard deviation. All experimental data were treated by SPSS program (SPSS version 21, SPSS Institute, Chicago, IL, USA). One-way ANOVA and followed by Dunnet post hoc test were used to examine the difference between groups. A p $<0.05$ was considered as a statistically significant.

\section{RESULTS AND DISCUSSION}

In this study, we used tinocrisposide as a test compound which was isolated from methylene chloride fractions of T. crispa stems. The isolation process was conducted according to our previous method by Pachaly and Adnan [8]. The structure of the compound was identified spectroscopically and confirmed with previous data in our publication.

The compound was namely identified by Fourier-transform infrared (FTIR) and ultraviolet (UV) spectrophotometry and analyzed by gas chromatography-mass spectrometry (GC-MS). Spectral data of the compound were as follows, FTIR (KBR pellet, $\mathrm{cm}^{-1}$ ): 3411 was for $0-\mathrm{H}$ stretch, 1654 was $\mathrm{C}=\mathrm{O}$ stretch, 1708 for $\gamma$-lactone, 2924, was for $\mathrm{Ar}-\mathrm{H}$, 1516 and 1437 were for $\mathrm{C}=\mathrm{C}$ stretch, 874, 816, and 760 were for $\mathrm{C}-\mathrm{H}$ bending. UV in $\mathrm{MeOH} \mathrm{nm:} 210$ (furan ring). GC-MS fragments (retention time 2.5000): 83, 98, 238, 310, 327

\section{RAW 264.7 cell viability}

Various concentrations of tinocrisposide were treated with RAW 264.7 cells for $24 \mathrm{~h}$ with MTT method to find the appropriate concentrations that exert no toxic and a false-positive effect. This experiments showed that tinocrisposide concentrations of 3.125, $6.25,12.5,25,50$, and $100 \mu \mathrm{M}$ gave $\%$ viability cells of $107.43 \pm 4.10$, $99.09 \pm 3.76,91.32 \pm 1.57,84.40 \pm 0.64,80.00 \pm 1.49$, and $73.74 \pm 1.95 \%$, respectively (Table 1). All tinoscrisposide-treated concentrations showed \% viability of 264.7 cells higher than $50 \%$. It can be assumed that tinocrisposide was a non-toxic compound against 264.7 RAW cells. Therefore, the tinocrisposide concentration in the inhibition of NO production experiment was adjusted in the interval of $1-100 \mu \mathrm{M}$.

\section{Nitrite reference curve}

$25 \mu \mathrm{l}$ of $\mathrm{NaNO}_{2}$ solution from each concentration of $100,50,25,12.5$, 6.25 , and $3.125 \mu \mathrm{M}$ were mixed with $25 \mu \mathrm{l}$ Griess reagent $(40 \mathrm{mg} / \mathrm{ml})$ and allowed at room temperature for $10 \mathrm{~min}$. Absorbency of solutions was measured using microplate plate reader at wavelength, $\lambda 560 \mathrm{~nm}$. Concentrations and absorbency data of experiments were presented in Table 2.

Concentrations and absorbance data of nitrite standard solution were processed with Microsoft Excel Software to get a calibration curve of nitrite solutions as presented in Fig. 2 and a regression equation, $y=0.002 x+0.055$. It showed a linear correlation between nitrite solution in interval concentration of 3.25-100 $\mu \mathrm{M}$ with their absorbance, with coefficient correlation, $\mathrm{R}^{2}=0.998$.

\section{Effect of tinocrisposid on NO production in LPS-stimulated RAW} 264.7 cells

Tinocrisposide effect on inhibition of NO production in LPSstimulated RAW 264.7 cells was assayed by quantification of nitrite accumulation in medium culture using Griess reagent. This method based on diazotization reaction that was firstly described by Griess in 1879. Griess reagent contains sulfanilamide and $N$-(1-naphthyl) ethylenediamine dihydrochloride (NED) in acid condition $\left(\mathrm{H}_{3} \mathrm{PO}_{4}\right)$ to quantitate the major metabolites of NO (nitrous oxide) such as nitrite and nitrate, in a variety of biological fluids, such as plasma, serum, urine, and culture medium.

Formed nitrite $\left(\mathrm{NO}_{2}^{-}\right)$in medium reacts under acidic condition with sulfanilamide to form a diazonium cation which subsequently couples to the aromatic amine NED to produce red-violet, water-soluble azo dye that can be quantified spectrophotometrically at a wavelength, $\lambda$ $560 \mathrm{~nm}$. In this experiment, nitrite was released into the supernatant of the medium as a response to inflammation of 264.7 RAW cells that have been stimulated by LPS. RAW cells were treated with various concentrations of tinocrisposide $1,5,25,50$, and $100 \mu \mathrm{M}$, allowed for $1 \mathrm{~h}$, stimulated with LPS, and incubated for $15 \mathrm{~h}$ at $37^{\circ} \mathrm{C}$ in a humidified atmosphere containing $5 \% \mathrm{CO}_{2}$.

The intensity of azo dye that formed from the reaction of dissolved nitrite in cell supernatant with Griess reagent was quantified with a microplate reader at a wavelength, $\lambda 560 \mathrm{~nm}$. Reading absorbance of samples was calculated using the regression equation of nitrite solution standard that gave a linear correlation between concentrations of nitrite solution and the absorbance of produced red-violet azo dye, to get nitrite concentration in the medium sample and the medium control.

LPS-stimulated 264.7 RAW cells were used as positive control, and 264.7 RAW cell that was not stimulated with LPS and not treated with tinocrisposide was used as negative control. Dexamethasone was used as nitrite inhibitor standard. Our experiment found that treating of tinocrisposide concentration of $1,5,25,50$, and $100 \mu \mathrm{M}$ against LPSstimulated RAW cells gave nitrite production concentrations of 39.23 , $34.0,28.9,20.25$, and $16.3 \mu \mathrm{M}$, respectively, and with \% inhibition of $22.67,33.00,43.03,60.1$, and 68.00, respectively (Fig. 3)

${ }^{a} \mathrm{p}<0.05$ indicated a significant difference between treated data value and unstimulated control group (negative LPS). ${ }^{b} \mathrm{p}<0.05$ indicated a significant difference between treated data value and untreated group (positive LPS). ${ }^{c} \mathrm{p}>0.05$ indicated no significant difference between treated data value and standard drug (dexamethasone)

Anti-inflammatory effect of tinocrisposide was studied by measuring NO production in LPS-stimulated RAW 264.7 cells. Cellular model

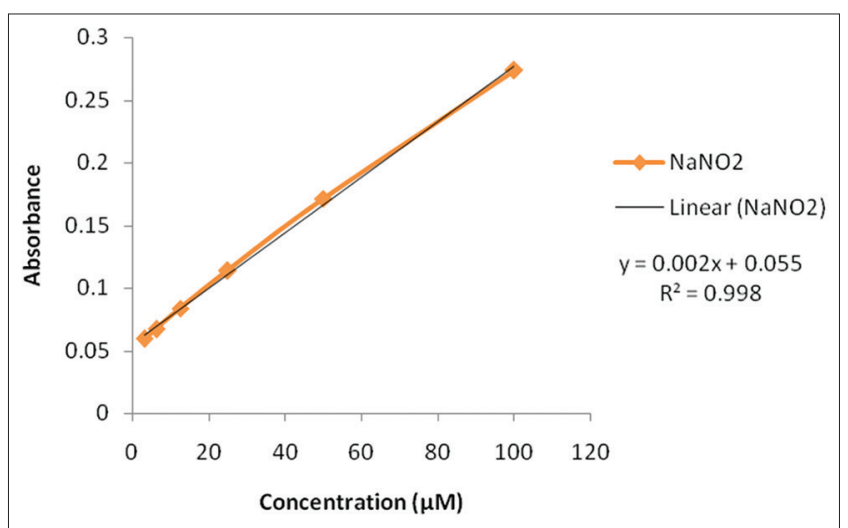

Fig. 2: Calibration curve of nitrite solution

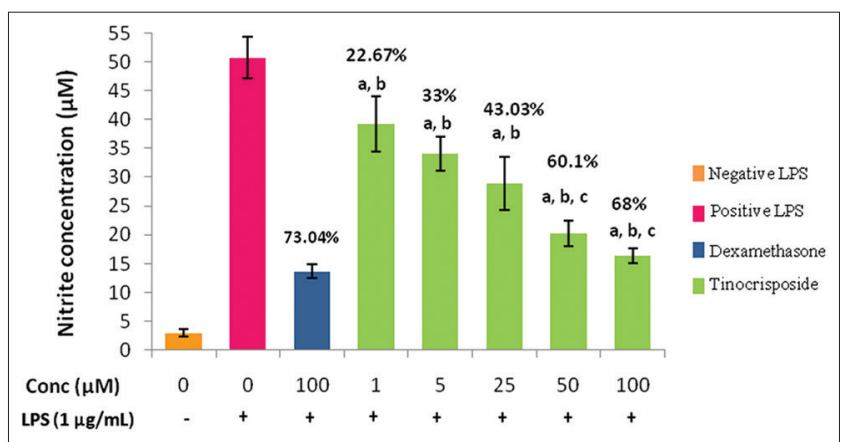

Fig. 3: Effect of tinocrisposide on the nitric oxide production in lipopolysaccharides (LPS)-stimulated cells. Cells were preincubated with compound for $1 \mathrm{~h}$ and then incubated with LPS for $15 \mathrm{~h}$ at $37^{\circ} \mathrm{C}$ in humidified atmosphere containing $5 \% \mathrm{CO}_{2}$. Error bars represent the standard deviation of triplicate values. 
Table 1: Effect of tinocrisposide on 264.7 cell viability

\begin{tabular}{ll}
\hline Concentration $(\mu \mathbf{M})$ & Average of \% cell viability \\
\hline 3.125 & $107.43 \pm 4.10$ \\
6.25 & $99.09 \pm 3.76$ \\
12.5 & $91.32 \pm 1.57$ \\
25 & $84.40 \pm 0.64$ \\
50 & $80.00 \pm 1.49$ \\
100 & $73.74 \pm 1.95$ \\
\hline
\end{tabular}

The results were represented as mean $\pm S D, n=3$. SD: Standard deviation

Table 2: Absorbance data of nitrite standard

\begin{tabular}{lllll}
\hline Concentration $(\mu \mathbf{M})$ & \multicolumn{2}{l}{ Absorbance } & Average \\
\cline { 2 - 4 } & $\mathbf{1}$ & $\mathbf{2}$ & $\mathbf{3}$ & \\
\hline 3.125 & 0.0591 & 0.0588 & 0.0609 & 0.0596 \\
6.25 & 0.0676 & 0.0665 & 0.0679 & 0.0673 \\
12.5 & 0.0853 & 0.082 & 0.0839 & 0.0837 \\
25 & 0.1152 & 0.114 & 0.1128 & 0.114 \\
50 & 0.1718 & 0.171 & 0.171 & 0.1713 \\
100 & 0.2747 & 0.2756 & 0.2709 & 0.2737 \\
\hline
\end{tabular}

of LPS-stimulated macrophage is extensively used to measure antiinflammatory activity. NO production was determined by nitrite $\left(\mathrm{NO}_{2}^{-}\right)$, which is one of two primary, stable, and non-volatile breakdown products of NO. This assay depends on a diazotization reaction that was originally described by Griess (1879). This reagent uses sulfanilamide and NED under acidic (phosphoric acid) conditions to detect $\mathrm{NO}_{2}^{-}$in many of biological and experimental liquid matrices such as plasma, serum, urine, and tissue culture medium. $\mathrm{NO}_{2}{ }^{-}$produced in biological and experimental fluid turns Griess reagent into pink-purple color when mixed together. The intensity of the color is measured and higher intensity of pink-purple color indicates higher $\mathrm{NO}_{2}{ }^{-}$production. In this study, nitrite was released into cell culture supernatants in response to inflammation.

This study compares NO production of LPS-stimulated cell treated with tinocrisposide with a positive control, a negative control, and a standard drug. Positive control used was cell exposed to LPS only. Since there is no treatment toward the cell, it was expected that the positive control produces the highest NO production. Meanwhile, a negative control of the study is untreated cell without LPS induction. The untreated cell was expected to produce lowest NO since there was no exposure to the inflammatory stimulus. Dexamethasone, a well known for its anti-inflammatory activity was used as a standard drug with exposed LPS. Results of this study showed that tinocrisposide able to reduce NO production in LPS-induced inflammatory in RAW 264.7 cells in a dose-dependent manner. During inflammatory process, upregulation of inducible NO synthase (iNOS) generates NO which is one of the proinflammatory mediators. Upregulation of iNOS can be contributed by inflammatory stimuli such as cytokines, IL, and bacterial endotoxin. This study stimulates the RAW 264.7 cells using LPS. LPS is bacterial endotoxin that found in the outer membrane of Gram-negative bacteria cell walls. Thus, in response to inflammatory stimuli, high level of NO is generated [28]. Exposure of RAW 264.7 cells to LPS upregulates iNOS and pre-treatment of the cell with varying compound concentration (1, $5,25,50$, and $100 \mu \mathrm{M}$ ) before LPS induction was able to reduce the NO production.

Tinocrisposide used was able to decrease NO production even at low concentration when NO production is compared against the positive control. At high concentration used $(100 \mu \mathrm{M})$, NO produced is $16.3 \mu \mathrm{M}$ and dexamethasone is $13.68 \mu \mathrm{M}$, this indicated that there was no significant difference between treated and reference. This suggests that compound possesses good potential as an anti-inflammatory agent. This was based on trend seen in NO generated. Meanwhile, the effect to dose used in this study did not affect cell viability since the test dose chosen $(1,5,25,50$, and $100 \mu \mathrm{M})$ was based on cell viability study conducted before NO determination study. Therefore, the NO reduction effect observed is based on tinocrisposide action and not due to a reduction in the cell population.

MTT assay was conducted to determine the cytotoxic effects of tinocrisposide on RAW 246.7 cells. The cell lines were incubated at various concentrations for $24 \mathrm{~h}$, and cytotoxicity was determined using a microplate reader. Meanwhile, the $\mathrm{IC}_{50}$ value was determined from the linear regression of the experimental data. MTT assay widely employed in cell biology for the study of growth factor, cytokines, and cytotoxicity of chemotherapeutic agents since it provides a simple and quantitative method for cell population's assessment in response to external factors exposure [29].

Based on the results of one-way ANOVA, the overall $p<0.05(p=0.00)$ this conclude that there were statistically significant differences between groups. The Dunnett's test is used to compare one control group against several treatment groups. In the Griess Assay, tinocrisposide at a concentrations of 50 and $100 \mu \mathrm{M}$ showed $\mathrm{p}>0.05(\mathrm{p}=0.249$ and 0.898, respectively); this means that there were no statistically significant differences between treatment group and dexamethasone. In the cytotoxic assay against RAW 264.7 cells, tinocrisposide at concentration $3.125 \mu \mathrm{g} /$ $\mathrm{ml}$ also showed $\mathrm{p}>0.05(\mathrm{p}=0.134$ and 0.241$)$, this means that there were no statistically significant differences between treatment group and control.

\section{CONCLUSION}

In summary, the present study showed that tinocrisposide, an isolated compound of T. crispa stem, decreased NO production in a dosedependent manner, where the significant inhibition was shown at concentration of 50 and $100 \mu \mathrm{M}$ which NO production was 20.25 and $16.3 \mu \mathrm{M}$, respectively, and with inhibition of 60.1 and $68 \%$, respectively. This result indicated that there was no significant difference between inhibition data of sample with the data of dexamethasone standard.

\section{ACKNOWLEDGMENTS}

This work was supported by Rector of Andalas University to enhance research activity at Faculty of Pharmacy.

\section{AUTHOR CONTRIBUTIONS}

Conception and design of study: A.Z. Adnan, M. Taher, T. Afriani, D.I. Roesma, A.E. Putra. Acquisition of data: M. Taher, T. Afriani, A. Fauzana. Analysis an interpretation of data: A.Z. Adnan, M. Taher, T. Afriani, A. Fauzana. Drafting the manuscript: T. Afriani, A. Fauzana, D.I. Roesma, A.E. Putra. Revising the manuscript critically for important intellectual content: A.Z. Adnan, M. Taher, T. Afriani. Approval of the version of the manuscript to be published (all authors): A.Z. Adnan, M. Taher, T. Afriani, A. Fauzana, D.I. Roesma, A.E. Putra

\section{CONFLICT OF INTEREST}

None.

\section{REFERENCES}

1. Dweck AC, Cavin JP. A review of Andawali (Tinospora crispa). Personal Care Mag 2006;7:1-3.

2. Mohamad S, Zin NM, Wahab HA, Ibrahim P, Sulaiman SF, Zahariluddin AS, et al. Antituberculosis potential of some ethnobotanically selected Malaysian plants. J Ethnopharmacol 2011;133:1021-6.

3. Kongsaktrakoon B, Temsiririrkkul R, Suvitayavat W, Nakornchai S, Wongkrajang Y. The antipyretic effect of Tinospora crispa Mier ex. Hock F. and Thoms. J Pharm Sci 1994;21:1-6.

4. Sulaiman MR, Zakaria ZA, Lihan R. Antinociceptive and antiinflamatory activities of Tinospora crispa in various animal models. Int J Trop Med 2008;3:66-9.

5. Yokozawa T, Wang TS, Chen CP, Hattori M. Inhibition of nitric oxide release by an aqueous extract of Tinospora tuberculata. Phytother Res 2000;14:51-3.

6. Froemming GA. Antiproliferative and antioxidant effects of Tinospora 
crispa (Bratawali). Biomed Res 2011;22:57-62.

7. Zulkhairi A, Abdah MA, Kamal NH, Nursakinah I, Moklas MA, Hasnah B, et al. Biological properties of Tinospora crispa (Akar patawali) and its antiproliferative activities on selected human cancer cell lines. Malay J Nutr 2008;14:173-87.

8. Pachaly P, Adnan ZA. Tinocrisposid einneues furanoditepenglykosid aus Tinospora crispa Miers. Arch Pharm (Weinheim) 1992;325:705-8.

9. Adnan ZA, Pachaly P, Husni M, Almahdy A, Adrianti A. Pharmacological Assessment of The New Furanoditerpenglycoside, Tinocrisposide from Tinospora crispa. Halle, Germany: $43^{\text {rd }}$ Annual Congress of The Society of Medicinal Plant Research; 1995.

10. Guo W, Sun J, Jiang L, Duan L, Huo M, Chen N, et al. Imperatorin attenuates LPS-induced inflammation by suppressing NF-KB and MAPKs activation in RAW 264.7 macrophages. Inflammation 2012;35:1764-72.

11. Hong YH, Chao WW, Chen ML, Lin BF. Ethyl acetate extracts of alfalfa (Medicago sativa L.) sprouts inhibit lipopolysaccharide induced inflammation in vitro and in vivo. J Biomed Sci 2009;16:64-75.

12. Parham P. The immune system. Elements of the Immune Systems and their Roles in defense. Ch. 1. New York: Garland Publishing; 2000a.

13. Lee CJ, Chen LG, Liang WL, Wang CC. Anti-inflammatory effects of Punica granatum Linne in vitro and in vivo. Food Chem 2010;118:315-22.

14. O'Byrne KJ, Dalgleish AG. Chronic immune activation and inflammation as the cause of malignancy. Br J Cancer 2001;85:473-83.

15. Mequanint W, Makonnen E, Urga K. In vivo anti-inflammatory activities of leaf extracts of Ocimum lamiifolium in mice model. J Ethnopharmacol 2011;134:32-6.

16. He G, Karin M. NF-kappaB and STAT3-key players in liver inflammation and cancer. Cell Res 2011;21:159-68.

17. Guo W, Kong E, Meydani M. Dietary polyphenols, inflammation, and cancer. Nutr Cancer 2009;61:807-10.

18. Santangelo C, Rosaria V, Scazzocchio B, Benedetto RD, Filesi C, Masella R. Polyphenols, intracellular signalling and inflammation. Ann Ist Super Sanita 2007;43:394-405.

19. Vallabhapurapu S, Karin M. Regulation and function of NF-kappa B transcription factors in the immune system. Annu Rev Immunol 2009;27:693-733.

20. Bakkali F, Averbeck S, Averbeck D, Idaomar M. Biological effects of essential oils. Food Chem Toxicol 2008;46:446-75.

21. Serhan CN. System approach to inflammation resolution: Identification of novel anti-inflammatory and pro-resolving mediators. J Thromb Haemost 2009;7 Suppl 1:44-8.

22. Dalgleish AG, O'Byrne KJ. Chronic immune activation and inflammation in the pathogenesis of AIDS and cancer. Adv Cancer Res 2002;84:231-76.

23. Uma G, Balasubramaniam V, Kumar J. In-vivo screening of antiinflammatory activity in methanolic extract of Corbichonia decumbens (Forsk.) using various animal models of paw oedema. Int J Pharm Pharm Sci 2014;6:146-8.

24. Soundarajan N, Mohan D, Abbu R, Devasena R. Evaluation of cytotoxicity, oxidative stress, nuclear changes and pro-inflamatory cytokines induced by monocrotophos in human keratinocytes cells in vitro. Int J Pharm Pharm Sci 2015;7:160-4.

25. Kusmardi K, Hermanto D, Estuningtyas A, Tedjo A, Priosoeryanto PB. The potency of Indonesia's pomegranate peel ethanol extraxt (Punica granatum Linn) as anti-inflammatory agent in mice colon induced by dextran sodium sulfate: Focus on cyclooxygenase-2 and inos expressions. Asian J Pharm Clin Res 2017;12:370-5.

26. Kurian KN, Nair PH, Bhat GS. Evaluation of anti-inflammatory property of Melamin from Marine bacillus spp. Btcz 31. Asian J Pharm Clin Res 2015;3:251-5.

27. Mosmann T. Rapid colorimetric assay for cellular growth and survival: Application to proliferation and cytotoxicity assays. J Immunol Methods 1983;65:55-63.

28. Lee HS, Ryu DS, Lee GS, Lee DS. Anti-inflammatory effects of dichloromethane fraction from Orostachys japonicus in RAW

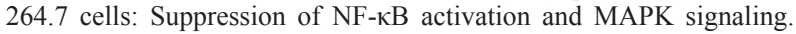
J Ethnopharmacol 2012;140:271-6.

29. Reddy AS, Abd Malek SN, Ibrahim H, Sim KS. Cytotoxic effect of Alpinia scabra (Blume) Náves extracts on human breast and ovarian cancer cells. BMC complement Altern Med 2013;12:314. 